\title{
Effect of Curing with NaCl Solution on Drying Characteristics of Fish Meat and Its Textural Changes during Drying
}

\author{
Zensuke Iseya, Satoshi Sugiura, and Hiroki Saeki* \\ Faculty of Fisheries, Hokkaido University, Hakodate, Hokkaido 041-8611, Japan \\ (Received April 8, 1998)
}

\begin{abstract}
Atka mackerel meats cured with $0.5-2.0 \mathrm{M} \mathrm{NaCl}$ containing $20 \mathrm{mM}$ Tris-acetate (pH 7.0) were incubated at $15^{\circ} \mathrm{C}, 30^{\circ} \mathrm{C}$ and $50^{\circ} \mathrm{C}$ and in $60 \%$ relative humidity for $0-16$ hours, and their drying characteristics and textural change during drying at different temperatures were simultaneously investigated. Slow moisture vaporization occurred at the initial drying period and the critical moisture content significantly decreased with an increase in the $\mathrm{NaCl}$ content of cured meats. In addition, the reduction of the drying rate in the later drying period was suppressed when $0.5 \mathrm{~mol} / \mathrm{kg}$ of $\mathrm{NaCl}$ were contained in the cured meats. Furthermore, at $15^{\circ} \mathrm{C}$ and $30^{\circ} \mathrm{C}$ drying, the increase in the shear force of dried products with the decrease in the moisture content was effectively suppressed by the curing with $\mathrm{NaCl}$. Such changes in the drying characteristics and texture would contribute to depression of the excess hardening and obtaining a long shelf-life of dried products.
\end{abstract}

Key words: fish meat, drying, $\mathrm{NaCl}$, moisture, texture

The basic purpose of food drying is to create an environment deleterious to the growth of spoilage mechanisms. When dried seafood products are manufactured, foodstuff is often cured with solutions introducing $\mathrm{NaCl}$ and other ingredients into meat. The water activity of dried products is effectively decreased by concentration of $\mathrm{NaCl}$ in the following drying process, and as a result, dried products can obtain better preservative property." However, if the drying temperature is too high and moisture rapidly decreases, a hard shell is developed on the surface of the materials and moisture is trapped on the inside. This phenomenon is called "case hardening", which impairs the preservative property of dried products. ${ }^{2)}$ Therefore, it is important to select a drying condition under which moisture vaporization from the surface continues until the moisture content reaches the desired value (required level).

Recently, biochemical changes in fish myofibrillar proteins during drying have been studied for introducing scientific quality control into the production of dried fish products. Raghunath et al. ${ }^{3)}$ found a decline in sulfhydryl groups in the dried meat of Japanese threadfin bream. Ito et al..$^{4)}$ and Tanbo et al. ${ }^{5)}$ observed production of crosslinked myosin heavy chains in some cured and dried fish meats. They suggested that such structural change in protein would affect the textural formation of dried meat. Nanbu et al..$^{6,7)}$ also investigated the osmotic dehydration of fish meat with soaking in $\mathrm{NaCl}$ solutions and denaturation of myofibrillar protein during soaking and drying. These findings suggest that $\mathrm{NaCl}$ penetrated into fish meat affects structural changes with drying and also its drying characteristics. However, there are few studies focused on the relationship between the texture of dried fish products and moisture diffusivity.

The object of this study is to clarify the role of the curing process in manufacturing dried fish products from the view of the moisture diffusivity and the structural changes in fish meat. The moisture transportation occurred in cured fish meat and its textural change during drying at different temperatures were simultaneously investigated.

\section{Materials and Methods}

\section{Preparation of cured fish meat and its drying}

Fresh atka mackerel Pleurogrammus azonus (about $800-1,000 \mathrm{~g}$ ) within one day of postmortem was purchased at a local fish market. All other chemicals (reagent grade) were obtained from Wako Pure Chemical Industries, Ltd. (Osaka, Japan). Meat blocks of ordinary muscle were taken parallel to the muscle fiber at $1 \times 1 \times 6 \mathrm{~cm}$. Twelve meat blocks obtained from each fish were stuffed into cellulose tubes $(\phi=15.9 \mathrm{~mm})$ and cured in $2000 \mathrm{~m} l$ of $20 \mathrm{mM}$ Tris-acetate $(\mathrm{pH} 7.0)$ containing $0.5 \mathrm{M}, 1.0 \mathrm{M}, 1.5 \mathrm{M}$ and $2.0 \mathrm{M} \mathrm{NaCl}$ at $5^{\circ} \mathrm{C}$ for 13 hours. After removing from the cellulose tubes, cured fish meat thus obtained were incubated at $15^{\circ} \mathrm{C}, 30^{\circ} \mathrm{C}$ and $50^{\circ} \mathrm{C}$ and in $60 \%$ relative humidity for 0-16 hours in a humidity cabinet (Model PR-1G, Tabai Espec Corp., Tokyo, Japan). The air flow rate was regulated to $\leqq 2.5 \mathrm{~m} / \mathrm{s}$. Test samples thus obtained were adjusted to $40 \mathrm{~mm}$ length by cutting off both ends and were used for texture evaluation. As a control, raw fish meat was dried under the same conditions without curing.

\section{Measurement of moisture content and analysis of drying characteristics}

The dried samples were chopped (2-3 g) and incubated at $105^{\circ} \mathrm{C}$ for 16 hours, and the weight loss was estimated as moisture. When samples were dried at different temperatures, the changes in the drying rates were investigated and drying characteristic curves were drawn for comparing the moisture transportation occurring in each cured meat. The

\footnotetext{
* Author to whom correspondence should be addressed (e-mail saeki@pop.fish.hokudai.ac.jp; fax +81-138-40-5515).
} 
drying rate was expressed in a moisture content loss as a function of time. In drying characteristic curves, the moisture content at which an abrupt decrease in drying rate occurred is regarded as the critical moisture content.

\section{Measurement of $\mathrm{NaCl}$ concentration}

Each $2 \mathrm{~g}$ sample was homogenized in $18 \mathrm{ml}$ of cold distilled water and dialyzed against 10 volumes of distilled water at $4^{\circ} \mathrm{C}$ for 20 hours. The $\mathrm{NaCl}$ concentration of the dried meat was determined by measuring the amount of $\mathrm{NaCl}$ eluted into the water. The conductivity of the water after dialysis was measured by a conductivity meter.

\section{Mechanical assessment of texture}

The modified shear head of the Warner-Bratzler's apparatus was attached to a rheometer (Model RUD-JS, San Kagaku Co., Ltd., Tokyo, Japan), which is eminently suitable for measuring the texture of dried fish meat. ${ }^{8)}$ A test sample was attached between the sample stopper and the stainless cutter blade of $0.45 \mathrm{~mm}$ thickness, and it was cut by the blade at a speed of $140 \mathrm{~mm} / \mathrm{min}$. The shear force ( $\mathrm{gW}$ ) was measured as the highest load value during the sample cutting. There were no significant differences in these parameters among meat blocks from different individuals $(n=6, p>0.05)$.

\section{Statistical analysis}

Tukey's multiple range test ${ }^{\text {9) }}$ was performed by Minitab 10 system for personal computers (Minitab Inc., State Collage, PA, USA).

\section{Results and Discussion} Water diffusivity in fish meat cured with different concen-
trations of $\mathrm{NaCl}$

The moisture content and $\mathrm{NaCl}$ concentration of cured meat are listed in Table 1. When fish meats were cured with $\mathrm{NaCl}$ solutions, the quantity of $\mathrm{NaCl}$ permeated into the samples rose and reached a plateau at four hours for $0.5 \mathrm{M} \mathrm{NaCl}$, ten hours for $1.0 \mathrm{M} \mathrm{NaCl}$, and 12 hours for $1.5 \mathrm{M}$ and $2.0 \mathrm{M} \mathrm{NaCl}$ (data not shown). The final $\mathrm{NaCl}$ concentration of the cured meat increased with rising $\mathrm{NaCl}$ concentration of the curing solutions, and the increments of $\mathrm{NaCl}$ corresponded to about $50 \%$ of the concentration of the curing solutions. Although fish meat was swelled by curing with $0.5 \mathrm{M} \mathrm{NaCl}$, osmotic dehydration was observed in 1.0-2.0 M NaCl-cured meats, and their moisture content decreased with the increase in the $\mathrm{NaCl}$ concentration of the curing solutions. Figure 1 shows changes in moisture content of the cured meats during drying at $15^{\circ} \mathrm{C}, 30^{\circ} \mathrm{C}$, and $50^{\circ} \mathrm{C}$. The moisture content of the control (raw meat) and $0.5 \mathrm{M} \mathrm{NaCl}$-cured meat more rapidly decreased than that of 1.0-2.0 $\mathrm{M} \mathrm{NaCl}$-cured meats during the initial drying period. No drip-loss was observed in any of the samples during drying at $15^{\circ} \mathrm{C}$ and $30^{\circ} \mathrm{C}$. In drying at $50^{\circ} \mathrm{C}$, drip exudate was obviously observed in the control and $0.5 \mathrm{M}$ cured meats at the beginning of drying, whereas drip was slightly exuded from $1.0 \mathrm{M}-2.0 \mathrm{M}$ cured meat in which osmotic dehydration during curing process was observed. These results indicate that the curing process affects the moisture transportation during the

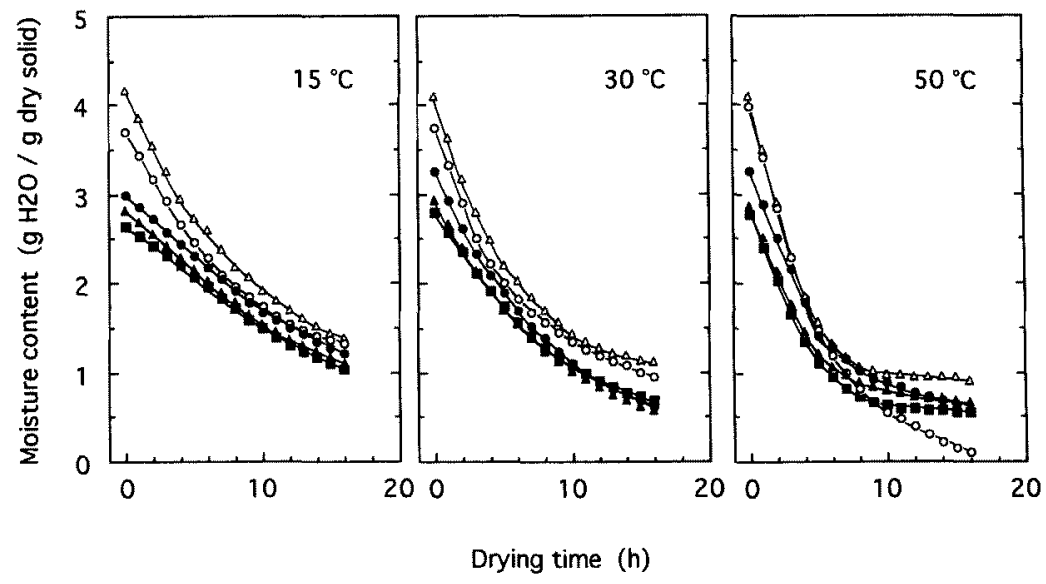

Fig. 1. Change in moisture content of cured fish meat during drying.

Fish meat blocks cured with $0.5(\triangle), 1.0(\bullet), 1.5(\triangle)$, and $2.0(\bullet) \mathrm{M} \mathrm{NaCl}$ solution $(\mathrm{pH} 7.0)$ were dried at $15^{\circ} \mathrm{C}, 30^{\circ} \mathrm{C}$, and $50^{\circ} \mathrm{C}\left(60^{\circ}\right.$ of relative humidity). As a control, raw meat block $(O)$ was also dried under the same conditions.

Table 1. Moisture content and $\mathrm{NaCl}$ concentration of fish meat cured in $\mathrm{NaCl}$ solutions

\begin{tabular}{cccccc}
\hline & Control & & \multicolumn{2}{c}{ NaCl concentration of curing solution (M) } \\
\cline { 3 - 6 } & $3.73 \pm 0.16$ & $4.04 \pm 0.12$ & $3.16 \pm 0.11$ & 1.5 & $2.90 \pm 0.08$ \\
\hline $\begin{array}{c}\text { Moisture } \\
\left(\mathrm{g} \mathrm{H}_{2} \mathrm{O} / \mathrm{g} \text { dry solid }\right) \\
\mathrm{NaCl} \\
(\mathrm{mole} / \mathrm{Kg})\end{array}$ & $0.11 \pm 0.01$ & $0.35 \pm 0.04$ & $0.62 \pm 0.08$ & $0.86 \pm 0.06$ & $1.13 \pm 0.06$ \\
\hline
\end{tabular}

Data was mean \pm S.D. of 3 experiments. 


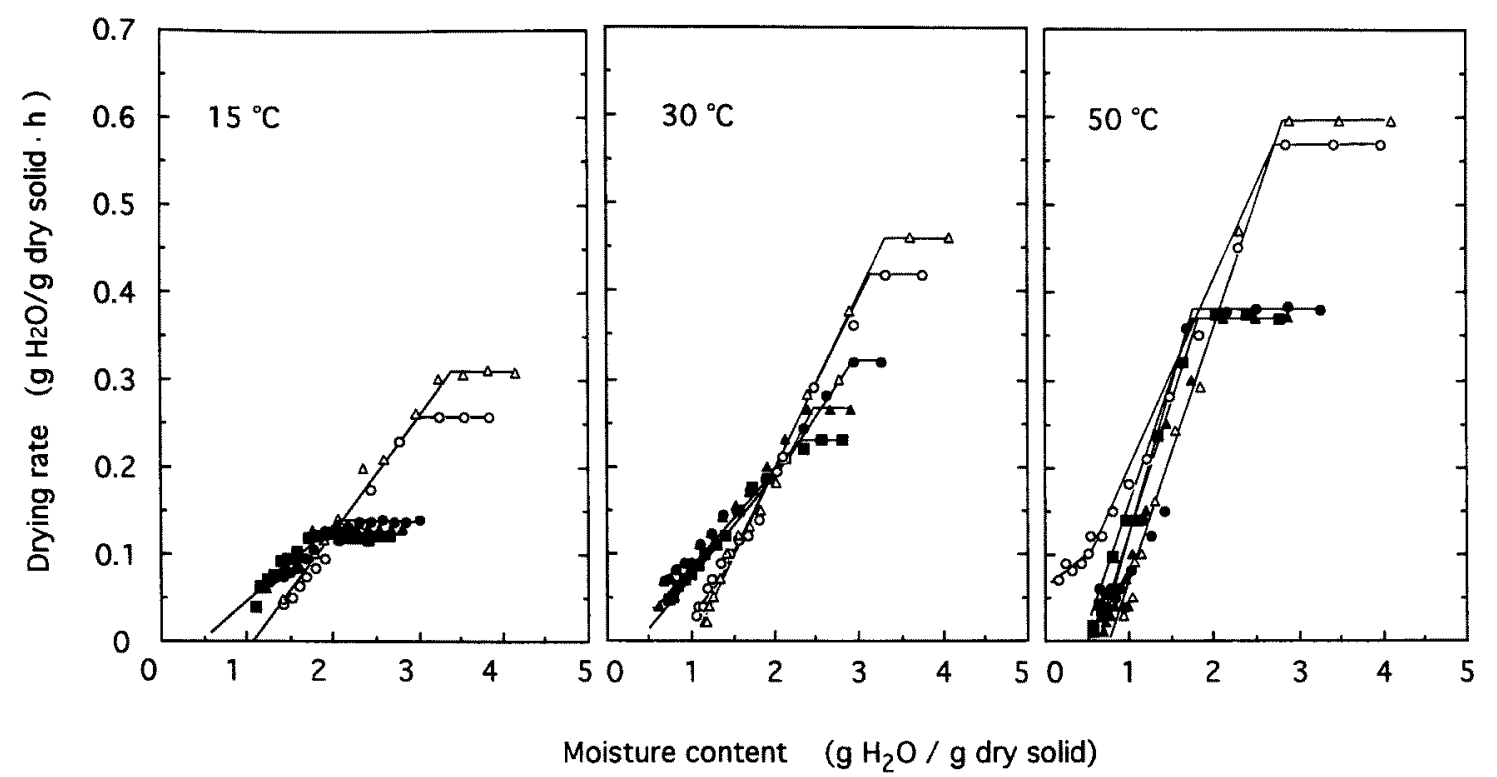

Fig. 2. Drying characteristic curve of cured fish meat. Symbols are the same as in Fig. 1.

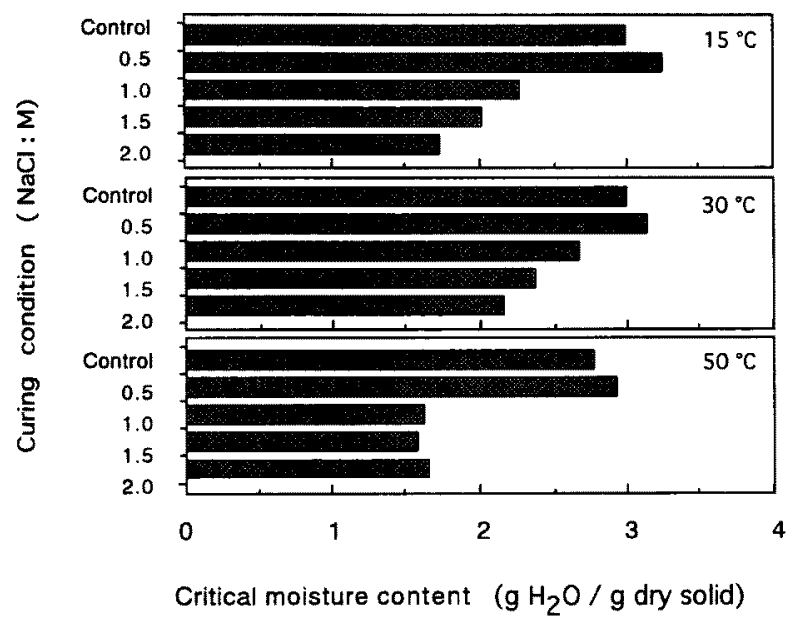

Fig. 3. Effect of curing critical moisture content of cured fish meat. Control: raw meat without curing.

following drying process.

The drying characteristic curves of the cured meat depicted from the data of Fig. 1 are shown in Fig. 2. The constant-rate drying period and the falling-rate drying period were observed in all the samples. The constant drying rates of the cured fish meats significantly decreased by curing with higher concentrations of $\mathrm{NaCl}$ solutions at all temperatures. However, as shown in Fig. 1, the moisture contents of 1.0-2.0 M NaCl-cured meats were always lower than that of $0.5 \mathrm{M} \mathrm{NaCl}$-cured meat. This occurred because the constant-rate drying periods were relatively short during the drying process and the initial moisture content of the cured meats was lowered by the osmotic dehydration which occurred in the curing process. Furthermore, in the falling-rate drying period at $15^{\circ} \mathrm{C}$ and $30^{\circ} \mathrm{C}$ drying, the reduction of the drying rate of $1.0-2.0 \mathrm{M} \mathrm{NaCl}$-cured meats took place at slower rates than that of the control and $0.5 \mathrm{M} \mathrm{NaCl}$-cured meat. As a result, the drying rates changed to be higher than those of the control and the 0.5 $\mathrm{M} \mathrm{NaCl}$-cured meat, when their moisture contents reached $2.0 \mathrm{~g} \mathrm{H}_{2} \mathrm{O} / \mathrm{g}$ dry solid. Although this effect was not observed in $50^{\circ} \mathrm{C}$ drying, this is because much drip exudation occurred in the control and the $0.5 \mathrm{M} \mathrm{NaCl}$-cured meat during drying. These results indicate that an effective moisture vaporization from the surface of fish meats was continued by curing with $\mathrm{NaCl}$. The results of Fig. 3, which show that significant decrease in the critical moisture content was caused by curing with $\mathrm{NaCl}$, also support this interpretation.

\section{Effect of $\mathrm{NaCl}$ on textural change in cured meat during drying}

As presented in Fig. 4, changes in the shear force of cured meats were greatly dependent on the drying temperature. At the beginning of drying at $50^{\circ} \mathrm{C}$, the shear force of all the samples decreased with the exudate of the drip. In particular, the control and $0.5 \mathrm{M} \mathrm{NaCl}$-cured meat, in which much drip exudate was observed, became porous dried products as the drying progressed. As a result, their shear force was lower than that of $1.0-2.0 \mathrm{M}$ cured meats during heating process. This result indicates an undesirable textural change of cured meat occurred at high temperature-drying would be suppressed by curing with high concentration of $\mathrm{NaCl}$.

On the other hand, in drying at $15^{\circ} \mathrm{C}$ and $30^{\circ} \mathrm{C}$, the shear force of all samples increased, although the increasing rate at $30^{\circ} \mathrm{C}$ diminished when the moisture content reached below $1.8 \mathrm{~g} \mathrm{H}_{2} \mathrm{O} / \mathrm{g}$ dry solid. It was also confirmed that there was no difference in the shear force changes among the five samples containing different amounts of $\mathrm{NaCl}(p>0.05)$. However, the moisture contents of the dried meats obviously differ from one another when compared at the same drying period, and it is apparent that the moisture content is an affecting factor in developing the texture of dried meat. Thus, we investigated the relationship between the shear force and the moisture 


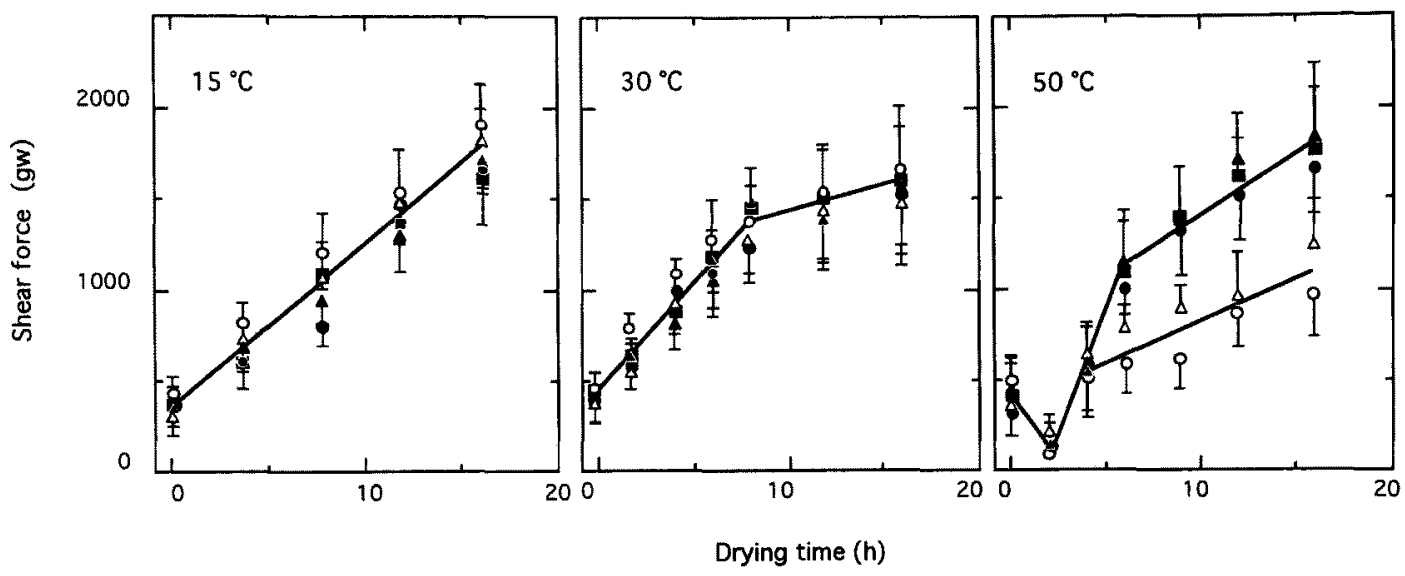

Fig. 4. Change in shear force of cured fish meat during drying.

Symbols are the same as in Fig. 1. Error bar is a standard deviation $(n=6)$.

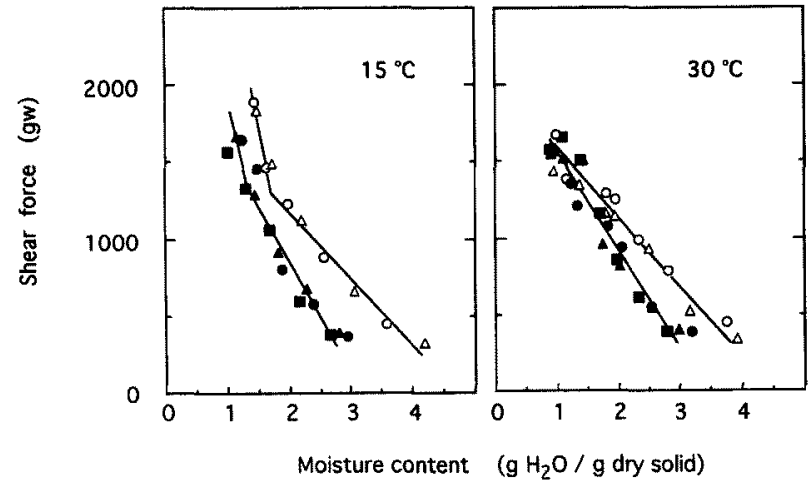

Fig. 5. Relation between shear force and moisture content of dried fish meat.

Symbols are the same as in Fig. 1. Open and closed symbols mean the low and high-salted groups, respectively,

content of the cured meats at $15^{\circ} \mathrm{C}$ and $30^{\circ} \mathrm{C}$. As shown in Fig. 5, there was no difference in the change in the shear force dependent on the moisture decrease between the control and $0.5 \mathrm{M} \mathrm{NaCl}$-cured meat (named the low-salted group), or among 1.0-2.0 M NaCl-cured meats (named the high-salted group) at all temperatures $(p>0.01)$. However, a significant difference in the relationship between the shear force and the moisture content was observed between two such groups of fish meats $(p<0.01)$. The shear force of the high-salted group was always lower than that of the low-salted group during drying at $15^{\circ} \mathrm{C}$ $(p<0.01)$. For example, the shear force of the high-salted group was lower than that of the low-salted group by 1.5 times at $1.5 \mathrm{~g} \mathrm{H}_{2} \mathrm{O} / \mathrm{g}$ dry solid of moisture content, and by 2.2 times at $2.5 \mathrm{~g} \mathrm{H}_{2} \mathrm{O} / \mathrm{g}$ dry solid of moisture content. This result indicates that curing with $\mathrm{NaCl}$ effectively depresses the hardening of dried fish meat products. Although the same trend was also observed in $30^{\circ} \mathrm{C}$ drying, which diminished with an increase in drying temperature. Therefore, it is apparent that drying at lower temperature is desirable for hindering an excess hardening of dried products.

The textural difference between the two sample groups (shown in Fig. 5) would reflect the development of a hard shell on the surface of the dried products. In fact, when the low-salted group was dried in $15^{\circ} \mathrm{C}$ and $30^{\circ} \mathrm{C}$, a hard shell was rapidly developed on the outside of the samples, and an apparent moisture gradient between the deeper parts and the surface was observed. Therefore, suppression of the hard shell would contribute to the effective moisture vaporization observed in the high-salted group.

Thus far the role of the curing process in manufacturing dried fish products has been discussed as reducing the water activity of dried products by the addition of salt. In this study, it was further shown that the curing process would help to manufacture dried products with a long shelf-life by the suppression of "case hardening", and depress an excess hardening of dried fish meat products. These findings should be useful in understanding conventional manufacturing technology, preparing better quality products, and designing an effective process line.

\section{References}

1) L. B. Rockland and S. K. Nishi: Influence of water activity on food product quality and stability. Food Technol., 34, 42-51 (1980).

2) G. M. Pigotto and B. W. Tucker: Seafood, Effect of technology on nutrition, Marcel Dekker, New York, 1990, pp. 146-157.

3) M. R. Raghunath, T. V. Sankar, K. Ammu, and K. Devadasan: Biochemical and nutritional changes in fish proteins during drying, J. Sci. Food Agric., 67, 197-204 (1995).

4) T. Ito, N. Kitada, N. Yamada, N. Seki, and K. Arai: Biochemical changes in myofibrillar protein of cured walleye pollack meat induced by dehydration, Nippon Suisan Gakkaishi, 56, 999-1006 (1990).

5) T. Tanbo, N. Yamada, N. Kitada: Change in myofibrillar protein of cured house mackerel meat induced by dehydration. Nippon Suisan Gakkaishi, 58, 685-691 (1992).

6) S. Nanbu, H. Kiuchi, Y. Yamamoto, Y. Kawamori, Y. Funatsu, and K. Arai: Effect of sorbitol on change in myofibrillar protein of cured meat block from walleye pollack during dehydration. Nippon Suisan Gakkaishi, 61, 233-241 (1995).

7) S. Nanbu, H. Kiuchi, A. Ooishi, T. Kitajima, Y. Kaneko, and K. Arai: Effect of concentration of $\mathrm{NaCl}$ and sorbitol caused by dehydration on moisture content and water activity of cured meat from walleye pollack. Nippon Suisan Gakkaishi, 63, 748-756 (1997).

8) Z. Iseya, S. Sugiura, and H. Saeki: Procedure for mechanical assessment of textural change in dried fish meat. Fisheries Sci., 62, 772-775 (1996).

9) R. G. D. Steel and J. H. Torrie: Principles and procedures of statics (2nd Ed.), McGraw-Hill, New York, 1986, pp. 173-193. 